\title{
How Do Budget Deficits and Economic Growth Affect Reelection Prospects? Evidence from a Large Panel of Countries
}

\author{
Adi Brender ${ }^{\dagger} \quad$ and $\quad$ Allan Drazen ${ }^{\ddagger * *}$
}

February 2008

\begin{abstract}
Conventional wisdom is that good economic conditions and expansionary fiscal policy help incumbents get reelected, but this has not been tested in a large cross-section of countries. We test these arguments in a sample of 74 countries over the period 1960-2003. We find no evidence that deficits help reelection in any group of countries - developed and less developed, new and old democracies, countries with different government or electoral systems, and countries with different levels of democracy. In developed countries and in old democracies, election-year deficits actually reduce the probability that a leader is reelected, with similar, although smaller, negative electoral effects of deficits in the earlier years of an incumbent's term in office. Higher growth rates of real GDP per-capita raise the probability of reelection only in the less developed countries and in new democracies, but voters are affected by growth over the leader's term in office rather than in the election year itself and apparently only by growth not attributed to global growth. Low inflation is rewarded by voters only in the developed countries. The effects we find are not only statistically significant, but also quite substantial quantitatively. We also suggest how the absence of a positive electoral effect of deficits can be consistent with the political deficit cycle found in new democracies.
\end{abstract}

JEL Classification: D72, E62, H62

Keywords: political budget cycle, political business cycle, fiscal manipulation

\footnotetext{
${ }^{\dagger}$ Research Department, Bank of Israel, e-mail: adib@bankisrael.gov.il

${ }^{\ddagger}$ Department of Economics, University of Maryland, e-mail: drazen@econ.umd.edu

*We wish to thank Mark Duggan, Saul Lach, Esteban Klor, two anonymous referees, and seminar participants in the Hebrew University of Jerusalem, the Israeli Economic Association and the Research Department at the Bank of Israel for useful comments, as well as Assaf Shtauber, Lior Gallo, Yehuda Porath and Sagie Dagan for superb research assistance. Drazen wishes to thank the Israel Science Foundation, the National Science Foundation, grant 418412, and the Yael Chair in Comparative Economics, Tel Aviv University for financial support, as well as the Research Department of the Bank of Israel for its hospitality. The views expressed in the paper do not necessarily reflect those of the Bank of Israel.
} 


\section{Introduction}

Conventional wisdom is that incumbents use economic policy to help their re-election prospects, but its effectiveness is not clear a priori. Voters may interpret good macroeconomic results, for example, as indicating a highly able leader, using simple retrospective voting rules (Nordhaus [1989]) or more sophisticated inference (Rogoff and Sibert [1988], Rogoff [1990], and Persson and Tabellini [1990]). Conversely, voters may believe that leaders matter little for certain types of economic outcomes, including sustained economic growth, so that voting might be largely unaffected by measures of good economic performance. In fact, a growth spurt in the election year itself might be especially suspicious and hence could affect voters negatively.

Empirical research on pre-electoral manipulation has mainly focused on the existence of pre-electoral expansions themselves rather than on whether expansionary policies or good economic outcomes succeed in attracting votes (though, at least for developed countries, little evidence of a political cycle in economic activity has been found). ${ }^{1}$ Existing direct tests of the effects of economic growth on the probability of reelection are for developed countries, where the effect of growth on reelection was found to be generally insignificant (with the exception of the U.S. $)^{2}$. No similar analysis has been done for less developed countries.

The lack of convincing evidence for a political business cycle led researchers to focus on political cycles in fiscal aggregates (election-year increases in deficits and expenditures or cuts in taxes). As with the effect of good economic performance, there are arguments both ways as to whether loose fiscal policy helps or harms an incumbent's reelection chances. Fiscal expansion reflected in higher supply of public goods or transfers - may signal competence, as in the work of Rogoff cited above, though the argument relies on rational voters being imperfectly informed. Second, if a "strong economy” gains votes, incumbents may use expansionary fiscal policy to stimulate the economy. Politicians however may have very limited ability to manipulate the

\footnotetext{
${ }^{1}$ Alt and Chrystal (1983) and Alesina, Roubini, and Cohen (1997) summarize empirical studies for the United States as showing little evidence of a political business cycle, a point reinforced by Faust and Irons (1999). Similarly, there is no strong evidence of a political cycle in unemployment or economic growth in other developed economies (Paldam [1979], Lewis-Beck [1988], Alesina, Roubini, and Cohen [1997]).

2 See Powell and Whitten (1993), Paldam (1991), Strøm and Lipset (1984) and Lewis-Beck (1988). For the U.S., Fair (1978) found a significant effect of growth on voting in presidential elections, as did Alesina and Rosenthal (1995).
} 
economy successfully or to accurately time the expansion to happen just before the elections. ${ }^{3}$ Moreover, if manipulating economic activity is considered harmful (in terms of "unsmoothing" consumption, inducing investment cycles, etc.), well-informed voters should punish rather than reward such policies at the polls, even more so if it is perceived as electorally motivated. ${ }^{4}$ Another argument is that spending targeted to specific groups may be quite effective in gaining votes for the incumbent, though it may lose votes if it is perceived as electoral manipulation. ${ }^{5}$ More generally, voters may simply prefer low taxes and high spending and reward politicians who deliver these, even though such a response requires some sort of “fiscal illusion”.

Many empirical studies find evidence of a political budget cycle, with the common view that political budget cycles are more a phenomenon of less developed than of developed countries. ${ }^{6}$ Nevertheless, direct tests of the effect of fiscal performance on reelection probabilities are even fewer than those testing the effect of macroeconomic conditions, and there are none on the national level of which we are aware. Alesina, Perotti, and Tavares (1998) come closest in their study of the political consequences of fiscal adjustments in a cross section of OECD countries. They find that that fiscal austerity has positive rather than negative political effects at the national level, but their analysis is focused on cabinet changes and opinion polls, rather than on election results. Peltzman (1992), Brender (2003), and Drazen and Eslava (2007) examine the direct effect of fiscal performance on reelection at the state and local level in a single country (the United States, Israel, and Colombia respectively), and find that voters punish - rather than reward - loose fiscal policies in general, as well as in election years. None of these country studies examines directly whether fiscal expansions during election years at the national level help

\footnotetext{
${ }^{3}$ Moreover, fiscal contractions may in fact be expansionary under certain circumstances. See Giavazzi and Pagano (1990), Bertola and Drazen (1993), and Alesina and Perotti (1997).

${ }^{4}$ Peltzman (1992), for example, shows that voters in the U.S. are less likely to support a state or local official who has increased overall spending before the election.

${ }^{5}$ Drazen and Eslava (2006), however, present a model of targeted spending in which an expenditure cycle may exist even if a targeted group of voters believes it is being targeted.

${ }^{6}$ Shi and Svensson (2006) find that, in an election year, the government surplus falls significantly in less developed but not in developed countries. Persson and Tabellini (2003, chapter 8) find a significant political revenue cycle in both developed and less-developed democracies over the period from 1960 to 1998, but no political cycle in expenditures, transfers, or the overall budget balance. Brender and Drazen (2005a) argue that the political budget cycles that these and other researchers have found in such large panel studies are driven by the experience of "new democracies", that is, by the experience of newly democratic countries in the first four elections after the transition to democracy. It is the strong fiscal cycle in these countries that accounts for the finding of a fiscal cycle in larger samples including these countries, no matter what other controls are included, which disappears once the new democracies are removed from the larger sample. For a summary see Drazen (2001) or Brender and Drazen (2005a).
} 
incumbents to get reelected. Moreover, any empirical conclusions one might draw should, strictly speaking, be limited to these countries, rather than applicable to a broad cross-section of countries analogous to the studies of the political budget cycle itself.

The existence of political budget cycles in some groups of countries and not in others suggests that they may reflect politicians' perception about the effectiveness of such measures. Further evidence suggesting different voter response is based on our analysis of the World Values Survey (Inglehart et al. [2004]). A statistically significant larger fraction of respondents in new democracies responded that a high level of economic growth or (separately) a stable economy is the most important target for their country among several policy targets. This effect is significant even when one controls for the level of income and the demographic structure of the country. The same analysis also showed a statistically significant negative correlation between the proportion of respondents who thought that these two targets were the most important and the level of GDP per-capita in a country. ${ }^{7}$ Hence, the empirical question arises as to whether the effect of economic growth on voter behavior is in fact different in new versus old democracies and in developed versus less developed countries, questions that we address here.

In short, existing studies do not provide a direct answer to the question whether election year deficits are a useful instrument for gaining reelection in countries in which a political deficit cycle has been found, nor in the broader cross-section of countries for which political budget cycles have been studied. That is, the key question which forms the basis of large cross-country studies of the political budget cycle has not been tested on a data set covering the same countries!

In this paper we look directly at the effects of fiscal performance and economic growth on reelection in various groups of countries. Using information on 350 election campaigns in 74 democracies we examine whether: 1) increased deficits during an election year raise the probability of reelection; 2) loose fiscal policies during the term in office help reelection; 3) GDP growth during the term in office, and specifically in the election year, helps incumbents to get reelected; and, 4) these forces work differently in countries at different levels of economic development, age and strength of democracy, or with different electoral or government systems.

The plan of the paper is as follows. In the next section we describe the dataset and variable definitions. Section 3 sets out the basic empirical results on the effect of deficits and growth on the probability of a leader's reelection. We find no evidence that larger deficits during

\footnotetext{
${ }^{7}$ For more details see Brender and Drazen (2007).
} 
an election year or over the term increase the probability of reelection, with rising deficits having a clear negative effect in developed and old democracies. Economic growth over the leader's term has a positive effect on the probability of reelection only in less developed countries and new democracies. In section 4 we examine the robustness of these findings to various different specifications, and show that the lack of support for the electoral value of deficit spending still holds. In section 5 we consider differences in the effects of deficits and growth on reelection in old and new democracies, as well as addressing the question of why incumbents in new democracies, where our earlier work found a clear political budget cycle, engage in expansionary fiscal policy even though it doesn't appear to gain votes. In section 6, we consider some alternative explanations of our results, and section 7 contains conclusions.

\section{Data and Variable Definitions}

The dataset used in this study is based on information from several sources, listed in Appendix Table A-1. (The statistical appendix and all appendix tables are available on the AER website or at www.econ.umd.edu/ drazen.) Fiscal data are taken mostly from the IFS, national accounts data from the World Bank's World Development Indicators and the IFS, information on the political structure of countries, their electoral system and additional political variables is constructed using the World Bank's database of Political Institutions (DPI) and data on the level of democracy are taken from the Polity IV dataset at the University of Maryland. A detailed description of the data sources and the construction of the variables appears in the statistical appendix. The combination of sources allows us to use data for 74 countries over the period 1960-2003. Overall we have useable information on 347 election campaigns that took place in periods where these countries were democratic. The countries and election campaigns are listed in Appendix Tables A-2 and A-3, respectively.

The key political variable REELECT is a binary variable with a value of 1 if the incumbent was reelected and 0 if he or she was not. Its construction was based on information from the "World Political Leaders 1945-2005" database of Zárate's Political Collections (ZPC) and from the "World Statesmen" encyclopedia. These data allow us to follow the terms of individual leaders in office from appointment to termination, and to associate them with election dates. The decision whether the prime minister or the president is the leader is based on the DPI dataset classification, as described in Persson and Tabellini (2003). Information on election dates

and results (presidential elections in presidential systems and parliamentary elections in 
parliamentary ones) is taken from the International Institute for Democracy and Electoral Assistance (IDEA) dataset "Voter Turnout Since 1945", from the International Foundation for Election Systems ELECTION GUIDE dataset and is supplemented by Binghamton University's Election Results archive.

We use two definitions of REELECT throughout the analysis. In the narrow definition we include only observations where the leader is running for reelection herself (either as the leader of her party in parliamentary elections or personally in presidential ones). We restrict the sample to leaders who were in office for at least two fiscal years prior to the elections and (other than those who were prevented from competing due to term limits) were candidates in the elections or retired within the month before the elections (in which case we classify the leader as losing reelection). In the expanded definition we add cases in which a leader was substituted by another candidate from his party under the following specific circumstances: 1) the leader died in the year before the elections; 2) the leader could not run for reelection due to legal term limits. In these cases the substitute leader (in the first case) or the candidate from the leader's party (in the second case) is treated as the incumbent. Additionally, in the expanded sample, we treat leaders who quit their job within a year before the elections as having lost reelection (that is, the binary variable REELECT has a value of 0 ), while in the narrow sample it is defined as a missing value as long as the leader quits more than a month before the elections. This latter classification is in line with the methodology of Alesina, Perotti, and Tavares (1998) and Brender (2003). ${ }^{8}$

In Table 1 we show the distribution of election campaigns according to the two definitions. There are 255 campaigns in the narrow sample, evenly split between successful and unsuccessful reelection attempts. About two thirds of the observations are in developed countries (23 OECD countries, see Table A-2), where the probability of reelection is somewhat higher than in the less developed countries. A breakdown of the sample between established and new democracies reveals that three quarters of the sample come from established democracies. The expanded definition adds 92 observations to the data, mostly in less developed countries. It also increases substantially the number of elections in new democracies. However, the definition change also substantially increases the proportion of campaigns in which the incumbent (or his substitute) is not reelected. This is a reflection of both the lower success rates of substitute

\footnotetext{
${ }^{8}$ Dropping the observations of leaders who quit in the year before the elections did not qualitatively affect any of our results.
} 
candidates, and the inclusion of those observations where the candidate has quit his job within the year before the elections.

The use of the narrow sample has the advantage of focusing only on the cases where the same person who led the government before the elections is the one seeking reelection. The homogeneity of this sample may reflect a clearer relationship between performance and reelection and avoids questions of the extent to which voters associate the new candidate with the policies of his predecessor. On the other hand, using the narrow definition means a substantial loss of information. We therefore present in the remainder of this paper results using both samples.

Fiscal performance is characterized by BALCH_term and BALCH_ey. The first variable reflects the change in the central government's balance (that is, budget surplus) to GDP ratio over the term in office by comparing the average balance/GDP ratio in the two years before the election year with that in the previous two years. The second variable is the change in the balance/GDP ratio in the election year relative to the previous year, which is an indicator for election year fiscal expansions. We use changes rather than the levels of these variables, as we believe that they better reflect the impact of the incumbent on policy outcomes. ${ }^{9}$ Both variables are calculated on the basis of IFS data, supplemented with GFS data, as described in Brender and Drazen (2005a). All the data are adjusted to fiscal years. (In 12 of the countries the fiscal year does not overlap the calendar year.) While in some cases it is not clear which fiscal year should correspond to the election year, Brender and Drazen (2005a) and others (for example, Alesina, Perotti and Tavares [1998]) find that the relationship between fiscal policy and the timing of elections is not very sensitive to the definition used. Nevertheless, we also present below some sensitivity indicators to show that our results are not qualitatively affected by the definition.

Our indicator for macroeconomic performance is GDPPC_gr, which is the average annual growth rate of real GDP per capita between the current and the previous election year. In cases where the leader assumed power after the previous elections, we calculate GDPPC_gr only over the period since his appointment. We also include, separately, in some of our equations, the real growth rate of GDP in the election year. Finally, we calculated the deviation of GDP from its long term trend (using a country-specific Hodrick-Prescott filter) for each country in each year, and used this variable in some of our equations as an additional control for the business cycle.

\footnotetext{
9 We also test later whether the initial size of the deficit affects our estimates.
} 
Descriptive statistics of the fiscal and macroeconomic variables in the various country categories in the expanded sample are presented in Table 1. Statistics for the narrow sample are shown in Appendix Table A-4 and Fisher's unit-root tests of the fiscal and macroeconomic variables, showing that they are all stationary, are presented in Appendix Table A-5. ${ }^{10}$ Correlations among the variables are given in Appendix Table A-6.

\section{The Effect of Deficits and Growth on Reelection}

We begin with the basic results. In Table 2 we show the effect of deficits and growth on the probability of reelection using Logit estimation. ${ }^{11}$ In columns 1 and 4 we show the unconditional effects in the narrow and expanded samples, respectively ${ }^{12}$. The equations show that voters are likely to punish rather than reward persistent budget deficits over the term in office (Remember that BALCH refers to a change in the budget surplus, so that a positive value of BALCH_term means that a higher surplus over the term of office increases the probability of reelection, or, equivalently, a larger deficit reduces reelection chances.) The coefficient of the change in the surplus to GDP ratio over the term in office, excluding the election year, is positive and statistically significant, indicating that the probability of reelection is increasing when the fiscal balance improves during the leader's term in office. Moreover, we find no indication that larger deficits during the election year (a negative value of BALCH_ey) increase the probability of reelection. In fact, we find a statistically significant positive effect of improved fiscal balances in the election year on reelection. That is, leaders who reduce the deficit during an election year, relative to the previous year, have a higher probability to be reelected.

Economic growth over the leader's term also has a positive effect on the probability of reelection, in both samples. It appears that voters attribute better macroeconomic performance, at least to some extent, to the functioning of their government, or that stronger macroeconomic performance allows governments to expand their services or cut taxes in a sustainable way, and by that gain electoral support. These findings contrast with those mentioned in footnote 2 that found no significant effect for developed countries. We argue below that this difference in results

\footnotetext{
${ }^{10}$ Fisher's test for panel unit root, as proposed by Maddala and Wu (1999), is used because it is suitable for an unbalanced panel.

${ }^{11}$ For a discussion of the robustness of the results to the use of fixed effects see Section 4 below. Probit equations yielded very similar results and are presented in Brender and Drazen (2005b).

12 All the equations are estimated using robust standard errors using the Huber/White/sandwich estimator of variance.
} 
is explained by distinguishing developed from less developed countries.

In addition to the fiscal and macroeconomic variables, we find that the probability of reelection is higher in developed countries ${ }^{13}$ and in countries with a majoritarian electoral system. In the narrow sample we also find that the probability of reelection is higher in new democracies, as compared to established democracies, but this latter relationship loses its significance in the expanded sample where the number of campaigns in new democracies is much larger on the one hand, but it includes many campaigns where the leader is not seeking reelection personally.

The effect of deficits and growth on reelection may well vary between developed and less developed countries. In Columns 2 and 5 of Table 2 we therefore look separately at the developed countries that constitute about two thirds of the narrow sample and one half of the expanded sample. We find that rising deficits over the term are associated with a lower probability of reelection, although the effect is weaker in the expanded sample. These results give no indication that expansionary fiscal policy helps a leader get reelected, and in fact it is likely to reduce his chances of reelection. The weaker effect in the expanded sample may reflect the fact that in the campaigns added to the narrow sample, the deficits over the term were due to the predecessors of politicians running as the "incumbent" and were therefore seen as less relevant by the voters.

The effect on reelection of the change in the fiscal balance in the election year itself is positive and statistically significant in both samples. These results show that not only that expanding the deficit in an election year is unlikely to increase the probability of reelection; in developed countries it lowers this probability.

The effect of macroeconomic performance on reelection, as reflected in the real growth rate of GDP over the term, is not significant in the developed countries, neither in the narrow nor in the expanded samples. This finding is consistent with the absence of a political business cycle in developed countries, suggested in the studies mentioned in footnote 1, as it appears that voting behavior in these countries is not significantly affected by higher economic growth.

The findings with respect to less developed countries (columns 3 and 6) are different in some respects from those for the developed countries. Nevertheless, voters in less developed countries also do not reward loose fiscal policies over the incumbent's term. The coefficient of the change in the budget balance to GDP ratio over the term is positive, and in the expanded sample

\footnotetext{
${ }^{13}$ Using the level of GDP per capita, instead of a binary variable for developed and less developed countries yielded insignificant results and did not qualitatively affect the coefficients of the other variables.
} 
it is statistically significant. The size of the coefficient is similar in both samples but the additional power in the expanded sample (the number of less developed countries' observations almost doubles in the expanded sample) overtakes the potential moderating effect of including candidates who were not personally in office for the full term before the elections.

The findings for the change in the ratio of the fiscal balance to GDP in the election year are notably different than those in developed countries. The coefficients on this variable are close to zero and are far from being statistically significant. On the one hand, these findings suggest that voters in less developed countries may be more tolerant towards expanding budget deficits in election years, but on the other hand they show that even in these countries, voters do not reward policies that generate election-year deficits.

Finally, economic growth over the term in office is strongly rewarded by voters in the less developed countries. Higher growth has a positive and statistically significant effect on the probability of reelection in both samples, consistent with the stronger evidence on the existence of a political business cycle in less developed countries. These findings suggest that in the less developed countries voters attribute more of the economic success of their country to their leaders. It is beyond the scope of this paper to explore why this is the case ${ }^{14}$, but we note that it is consistent with the findings of the World Values Survey mentioned in the Introduction.

Thus, we find out that the relationship between fiscal and macroeconomic performance and the probability of reelection, found in the broad sample of countries, reflect two distinct influences in developed and less developed countries. While loose fiscal policies have a negative effect on the probability of reelection in both sets of countries, deficit expansions in the election year are punished only in the developed countries, while in the less developed ones they have no significant effect. On the other hand, macroeconomic expansion has a positive significant effect on reelection in less developed countries and no effect in developed ones.

\section{Robustness}

Since the data are taken from a panel of countries it is possible that some of the results are driven by unobserved country characteristics that are correlated with both the probability of reelection and with the explanatory variables. In Table 3 we present the equations for the

\footnotetext{
${ }^{14}$ We can speculate that it may reflect the more important role of leaders in less developed countries in determining the direction of their country or in securing order and stability which are pre-conditions for growth, while these are taken for granted in developed countries.
} 
developed and the less developed countries using fixed effects Logit. The use of this procedure reduces the size of the sample, especially of the less developed countries, because countries that do not have cases of both won and lost elections are dropped. Nevertheless, our results are robust to this specification: the coefficients of the change in the fiscal balance during the term-in-office and the election years are positive in the developed countries, and economic growth has a positive effect on reelection in the less developed ones. The Hausman test does not reject the homogeneity restriction and suggests that the inclusion of the fixed effects does not alter the results. To avoid the loss of data due to the use of fixed effects the equations in the remainder of the paper are estimated without fixed effects. ${ }^{15}$

We also tested the robustness of our findings to alternative specifications. In Table 4 we report regressions where we allow for different effects of the change in the budget surplus and growth variables in developed and less developed countries by multiplying each one of them by a binary variable that receives a value of 1 for the respective group of countries and a different binary variable for the remaining countries. ${ }^{16}$ The results match those of Table 2 . We also tested (column 2 of the table) whether including the growth rate of GDP during the election year separately would affect the coefficient of the change in the election-year budget balance or has a stronger impact on voters than growth in the other years of the leader's term. We find that neither of these effects is supported by the data. ${ }^{17}$ We also found that the basic results are not affected when we control for the deviation of real GDP in the election year from its country specific longrun time trend, calculated using the Hodrick-Prescott filter (column 3), nor that the size of the budget surplus at the beginning of the term has an effect on our main results (column 5). Additionally, we tested (columns 4 and 7) whether the effect of the budget balance in election

\footnotetext{
15 Equations using random effects Logit are presented in Table A-7 in the appendix, and are very similar to the basic Logit equations. All the results in the remainder of the paper are not qualitatively affected by the use of either fixed effect or random effects nor by the associated reduction in the sample size (see Tables A-8 and A-19 in the appendix).

${ }^{16}$ For example, the entry BALCH_term*developed in a table refers to the change in the fiscal balance during the term in office in developed countries and the entry BALCH_term*less_developed refers to the same variable in less developed countries.

${ }^{17}$ The overall effect of growth in the election year in less developed countries remains positive even when the negative effect of the coefficient of growth in the election year is taken into account because its overall effect also includes the influence of growth over the term, which includes the election year.
} 
years is distinct from that in earlier years. ${ }^{18}$ We find that such an effect exists and is positive. That is, not only does an improved fiscal balance in general helps reelection, doing so in an election year is even more effective, but only in the developed countries. Moreover, we find no evidence for a positive effect of increased election-year deficits in the less developed countries. ${ }^{19}$

Persson and Tabellini (2003) among others argue that the structure of the political system and the electoral system have a substantial effect on the possibility and desire of leaders to engage in political manipulation, which would be reflected in PBCs. Brender and Drazen (2005a) find that differences across countries in the level (or strength) of their democratic system may affect the degree to which leaders may find it useful to engage in fiscal manipulation (and that voters would reward it). We therefore test below whether the effects of the fiscal balance and growth on reelection differ across these categories of countries, and whether there may be a group of countries where fiscal expansions during election years are rewarded. In Appendix Table A-9 we provide the breakdown of the samples into the various country categories, and separately for the developed and less developed countries and for the old and new democracies. In Appendix Table A-10 we show that controlling for the type of political system (parliamentary versus Presidential); having the elections on their predetermined date ${ }^{20}$; and the level of democracy (as measured by the country's Polity IV score) has no effect on the results. In Table A-11 we show that while the political and electoral systems and the level of democracy may influence the relationship between fiscal performance and reelection, in no case is there evidence that loose fiscal policies, or fiscal expansions during an election year, help an incumbent to win reelection. ${ }^{21}$ Finally, we find that growth has a positive effect on reelection in all the categories of less developed countries, but no statistically significant effect in any group of developed countries.

The effects of fiscal policy and macroeconomic performance that we find are not only

\footnotetext{
${ }^{18}$ For that purpose we substitute our variable of the deficit over the term, which excluded the election year, with a variable that includes the deficit in the election year. We then check whether the change in the deficit in the election year has an additional effect.

${ }^{19}$ We also tested and rejected the possibility that our findings for developed countries reflect a special effort by politicians (and special attention of voters) in the EU countries during the post-Maastricht period.

${ }^{20}$ If the election was held in the expected year we classified it as "predetermined"; otherwise it was classified as "early".

${ }^{21} \mathrm{~A}$ comprehensive discussion of these differences and the results for the expanded sample, which are qualitatively the same, are presented in the working paper version [2005b] of the paper.
} 
statistically significant, but also quite substantial quantitatively. ${ }^{22}$ We find that an increase of 1 percentage point in the central government surplus ratio to GDP can raise the probability of reelection by 3-5 percentage points in the developed/established democracies and that an increase of 1 percentage point in the surplus during an election year raises the probability of reelection by 7-9 percentage points. These magnitudes are broadly in line with those reported in Brender (2003) for similar variables in the local elections in Israel. In the less developed countries/new democracies raising the average growth rate during the term by 1 percentage point is associated with a 6.5-9 percentage points increase in the probability of reelection.

\section{Old and New Democracies}

Brender and Drazen (2005a) argued that the existence of a statistically significant political cycle in fiscal aggregates critically depends on the "newness" of the democratic regime; political budget cycles are found in the first four elections after the country becomes a democracy, but not in later elections. In Table 5 we test whether the prevalence of PBCs in new democracies is associated with a positive payoff to deficit spending at the polls. We estimate the previously specified logit equations on the full samples allowing for different effect of the full-term and election year budget balance, and of growth, in new and old democracies. Based on the results in Table 2 we also divide the old democracies between developed and less developed countries. ${ }^{23}$

We find that deficits reduce the probability of reelection in old democracies that are developed, but have no effect in less developed old democracies (columns 1 and 3). In the new democracies - the group of countries for which Brender and Drazen (2005a) found a significant political budget cycle - we find no significant effect of the fiscal balance on the probability of reelection. This is an unexpected finding, if one believes that the rationale for political budget cycle is that opportunistic leaders run deficits because it helps (or is believed to help) their reelection prospects. We discuss this in more detail at the end of this section.

We also find a significant positive effect of growth on reelection in the less developed old

\footnotetext{
${ }^{22}$ The detailed results are presented in Appendix Table A-12. The effect of the variables is calculated at the average points for the developed and less developed countries separately.

${ }^{23}$ There are only 11 observations of developed new democracies so we do not split the sample of new democracies. Estimating the equations with this additional breakdown did not change any of the results qualitatively. Results with the undivided sample of old democracies are reported in Table A-13. The results of equations estimated separately for new, old developed and old less developed countries are reported in Table A-14.
} 
democracies and in new democracies but not in old developed ones, consistent with the importance put on economic growth by respondents to the World Values Survey in new democracies and less developed countries. Columns 2 and 4 show that these effects are robust to the inclusion of cyclical fluctuations, as reflected in the deviation of GDP from its trend. ${ }^{24}$ It also shows that this effect is not stronger if growth takes place during the election year, as compared to earlier years in the incumbent's term, especially in new democracies. (See also Table A-13 in the appendix.) This finding contradicts much of the logic behind the PBC literature, which argues that fiscal expansions during election years are used to accelerate growth just before the elections. To summarize, not only are election-year fiscal expansions not rewarded by voters, even in the group of countries where they are most common, but even growth in the election year itself does not affect voters when growth over the entire term is controlled for. ${ }^{25}$

Our findings for new democracies raise a key question when compared with those of Brender and Drazen (2005a) where we found that political cycles in fiscal aggregates exist only in new democracies, where the effect is entirely due to higher expenditures in the election year. ${ }^{26}$ In this paper we find that even in new democracies there are no indications that fiscal expansions in the election year increase an incumbent's probability of reelection, either directly or via higher election year growth. Why then would rational politicians in new democracies engage in systematic fiscal expansions in election years, as found in our earlier paper?

One possible explanation of these joint findings is that the fiscal expansions in election years in new democracies do not represent an incumbent's attempt to gain voter support; instead, they reflect expenditures incurred in an attempt to consolidate democracy. As described in Brender and Drazen (2007), democracy is often not "consolidated" in new democracies, that is, it is not accepted unconditionally by all citizens. We argue that an election year may be an especially dangerous time for the existence of the democracy itself, and thus may be characterized by significant expenditures to retain popular support for the democratic regime in order to prevent its overthrow or subversion. We would then observe higher expenditures and

\footnotetext{
${ }^{24}$ The results are similar when we control for real GDP growth instead of the deviation from the trend.

${ }^{25}$ In Table A-15 we show that the effects of changes in the fiscal balance and growth on reelection in old versus new democracies are robust to different political and electoral systems, the level of democracy, and the timing (predetermined or early) of elections. A more detailed discussion and results in the expanded sample are available in Brender and Drazen (2005b).

${ }^{26}$ In Table A-20 below we show that there is no statistically significant difference in the effect of deficits due to higher expenditures and those due to lower revenue.
} 
deficits in an election year, but without fiscal expansion necessarily gaining votes for the incumbent over the challenger. Testing this hypothesis empirically is beyond the scope of this paper, but further conceptual discussion can be found in the above mentioned paper.

\section{Alternative Explanations}

To characterize our primary finding in a sentence: voters, especially in developed countries and established democracies, do not like deficits, particularly in election years. The negative electoral effect of deficits in some groups of countries and the lack of a significant positive effect in any group of countries seems quite clear.

We should stress that we are not arguing that there are no instances in individual countries - including in developed, established democracies - in which incumbents were reelected after running large election-year deficits (or defeated after enacting programs of fiscal austerity). There clearly are such examples, but our results indicate that this is not an empirical regularity. Nor are we arguing that our results show that incumbents do not use economic policy to try to improve their reelection chances, which they might do. What our results do indicate is that manipulation of fiscal aggregates will not generally be a successful reelection strategy, especially in developed, established democracies. Successful policy manipulation must take other forms, such as targeting some voters at the expense of others (as suggested by Drazen and Eslava [2006]). This is not uncommon and in no way contradicts our results.

In this section, we consider alternative explanations of our findings. One question that may arise with respect to these findings is that of causality. It may be argued that strong leaders have the political power to conduct conservative fiscal policies (see, for example, Roubini and Sachs (1989)) and at the same time have a better chance to be reelected. In order to control, at least to some extent, for this possibility we collected data on the share of the votes received by each leader in the previous election and his party's strength in the legislature, taking into account various aspects of the nature of the electoral system. When the leader is elected directly, the vote share he received in the previous election gives some indication of his popularity and thus his political strength. ${ }^{27}$ In a parliamentary system, the percent of seats in the parliament held by the

\footnotetext{
${ }^{27}$ In some countries with a presidential system it is not trivial to match the president with a specific party, or even a group of parties. We also tested for effects of the size of the coalition in the year before the elections and (jointly) the proportion of seats held by the leader's party within the coalition. This variable did not have a significant effect on the probability of reelection, nor affect any of the other coefficients.
} 
leader's party may, in a similar way, represent his popularity and indicate his ability to carry out his program. ${ }^{28}$ In Table 6 we show that none of the relationships we identified above is affected by the inclusion of these variables, although the additional variables have the expected (and in most cases, statistically significant) effect on the probability of reelection ${ }^{29}$. These findings suggest that the effect of improved fiscal positions on reelection is not merely a reflection of the use of the leader's political power to better control fiscal developments. ${ }^{30}$

An alternative explanation for our finding that growth has no effect on the probability of reelection in developed countries may be that it is due to the significant impact of global economic developments on the growth performance of these countries. If this is the case, it may still be that voters reward policy induced growth, but this component would not be observable in the data due to the dominant effect of global factors.

To test for this possibility we try to separate the effects of global economic developments by running a regression of the real growth rate of per-capita GDP during the leader's term on the product of the real growth rate of world GDP and the share of exports of goods and services in the country's GDP (both variables taken from the WDI). We estimated these regressions separately for developed and less developed countries. We then entered, separately, the predicted values from these regressions and the residual growth rates into our original regressions, instead of our original growth variable. In this way, the first variable GLOBAL_gr captures the effect of global developments while the second, DOMESTIC_gr captures mostly domestically induced growth. We use the same coefficient for all the countries in the group because a stronger or weaker response in a country to global developments may itself be a policy outcome.

The results of this estimation are reported in Table 6. We find that in the developed countries neither the effect of global growth nor the effect of domestically induced growth is statistically significant. This finding may suggest that in these countries even the domestic component of growth is attributed to the success of the business sector, rather than to the performance of the government. In the less developed countries we find that the global (exogenous) component of growth does not have a statistically significant effect on the probability of reelection, while the domestic component is the one that accounts for the highly

\footnotetext{
${ }^{28}$ Descriptive statistics of these two variables are presented in Appendix Table A-16.

${ }^{29}$ In Table A-17, we show the results are not affected by the fall in the number of available observations due to the inclusion of this variable, nor by alternative specifications of the political variables.

${ }^{30}$ Separate equations for the developed and less developed countries are shown in Table A-18.
} 
significant effect of growth that we find. This is consistent with a rational behavior of voters that reward their leaders only for growth that is related to domestic factors, which may be more reflective of their own performance. ${ }^{31}$ Finally, in both developed and less developed countries the division of growth into the domestic and global components did not affect qualitatively any of the other coefficients.

Another possibility is that voters are not bothered so much by deficits per se, but by inflation which itself is often caused by deficit spending. Inflation may also be the reason why we do not find a positive effect of growth on the probability of reelection in the developed countries, if it is positively correlated with growth. Shiller (1996), Lewis-Beck (1988) and Alesina, Perotti, and Tavares (1998), among others, find evidence that voters dislike inflation and punish governments that create it. To control for this possibility in Table 6 we added the inflation rate in the election year, the change in the inflation rate during the election year and the average inflation rate during the leader's term in office. We find that all these variables have a statistically significant negative effect on the probability of reelection in the developed countries, and no effect in the less-developed ones. However, the inclusion of these variables does not affect the relationship between the fiscal and growth variables and the probability of reelection. That is, our findings of dislike of deficits and indifference to growth reflect more than dislike of inflation.

Since we use annual data in our sample, the effects of budget deficits on reelection could be "clouded" by campaigns that take place in the early parts of the year, if the government expanded the deficit in the previous year or took corrective measure in the later part of the year, after the elections. While Brender and Drazen (2005a) find no evidence that larger fiscal expansions take place in election years in which the elections are in the later part of the year, we allowed for varying effects of the deficit if the elections are in the first half of the year, or in the second half. We find that there is no statistically significant positive effect of the deficit in the election year on reelection probabilities, either when the elections are in the first half of the year or in the second half. ${ }^{32}$ The results are not qualitatively affected by the use of fixed effects either

\footnotetext{
${ }^{31}$ In contrast, Leigh (2004), in a very different specification finds that higher world growth increases an incumbent's reelection chances in both developed and less-developed countries, and that the electoral reward to growth attributed to domestic factors is higher in richer countries.

${ }^{32}$ The $\mathrm{P}$ values of the coefficients of BALCH_ey in the developed countries were .036 and .03 for elections held in the first and second halves of the year, respectively. In the less developed countries the $\mathrm{P}$ values were .20 (with a positive coefficient) and .49 (based on equation 3 in Table 6). Similar results were found in the expanded sample. The results are available on request.
} 
(Table A-19).

Finally, we tested whether voters are sensitive to the source of fiscal expansion. ${ }^{33}$ We found that there is no statistically significant difference in the effect of deficits that are created by higher expenditures and those that are created by lower revenue, although in the developed countries the effect of revenue reductions (as a share of GDP) is somewhat larger. These results may seem surprising in light of the findings in the fiscal adjustments literature that expenditure based consolidations tend to be more successful (e.g., Alesina et. al. (1998)). However, Tavares (2004) shows that revenue based consolidations are more effective for right wing cabinets while expenditure based ones work for left wing cabinets.

\section{Conclusions}

In this paper we step backwards in the chain of reasoning underlying the opportunistic political budget cycle to test whether an increase in the government's budget deficit during an election year actually helps the incumbent get reelected. We find no evidence that this is the case in any of the groupings of countries we examine. This includes: developed countries, less developed countries; new and old democracies; countries with presidential or parliamentary government systems; countries with proportional or majoritarian electoral systems; and, countries with different levels of democracy. We also find that it makes no difference for the results whether the elections take place at their originally scheduled date or are called early.

In fact, we find that in developed countries and established democracies election-year deficit spending and tax cuts are punished at the polls. A worsening of the government's fiscal balance in the election year actually reduces the probability that the leader is reelected.

We find similar results for the effect of budget deficits in the earlier years of an incumbent's term in office. In most countries loose fiscal policies over the incumbent's term of office - reflected in larger budget deficits relative to earlier periods - are also associated with a statistically significant lower probability of reelection. Even when one cannot find a significantly lower probability, there is no evidence that deficits raise the probability of reelection. That is, in groupings of countries, deficits either lower the probability of reelection or have no statistically significant effect either way. The findings with respect to election year budget deficits may simply mirror negative voter reaction to budget deficits in other years as well. To the extent that

\footnotetext{
33 The detailed results appear in Table A-20.
} 
voters dislike deficits in general (that is, they are "fiscal conservatives"), it is probably especially difficult to persuade them that they are "good” in an election year. Such fiscal conservatism would lead rational voters to view election-year deficits as clear and costly electoral manipulation and react quite negatively.

We also find that strong macroeconomic performance, reflected in higher growth rates of real GDP per-capita, is associated with a higher probability of reelection only in the less developed countries and in the new democracies. Consistent with previous studies (other than in the US) we do not find significant effects of growth on reelection in developed countries. We also found that in the less-developed countries voters are affected by the overall growth performance over the leader's term in office, but with no additional effect for growth in the election year itself. This finding is not consistent with the proposition in the political business cycle literature that leaders could gain voter support by manipulating the economy to grow faster in election years.

Moreover, the effects we find are not only statistically significant, but also quite substantial quantitatively. An increase of 1 percentage point in the central government surplus ratio to GDP can increase the probability of reelection by 3-5 percentage points in the developed/established democracies and an increase of 1 percentage point in the surplus during an election year increases the probability of reelection by 7-9 percentage points.

Our results should raise further questions about the existence of political cycles in fiscal aggregates and especially in deficits as a widespread occurrence. We are not arguing that election-year political manipulation does not exist as a general phenomenon. It may take forms not affecting fiscal aggregates: changing the composition of spending (Drazen and Eslava [2007]) or targeting some voters at the expense of others (Drazen and Eslava [2006]). But, our results say clearly that running deficits in an election year is not an effective tool to help reelection and in fact is punished at the polls in developed countries that are established democracies. Politicians, take note! 


\section{References}

Alesina, A. and R. Perotti (1997), "Fiscal Adjustments in OECD Countries: Composition and Macroeconomic Effects,” IMF Staff Papers 44, 210-248.

Alesina, A., R. Perotti and J. Tavares (1998), “The Political Economy of Fiscal Adjustments”, Brookings Papers on Economic Activity 1:1998, 197-248.

Alesina A. and H. Rosenthal (1995), Partisan Politics, Divided Government and the Economy, Cambridge, UK: Cambridge University Press.

Alesina, A., N. Roubini and G. Cohen (1997), Political Cycles and the Macroeconomy, Cambridge, MA: MIT Press.

Alt, J. and A. Chrystal (1983), Political Economy, Berkeley, CA: Berkeley University Press.

Bertola, G. and A. Drazen.(1993), “Trigger Points and Budget Cuts: Explaining the Effects of Fiscal Austerity." American Economic Review 83, 11-26.

Brender, A. (2003), “The Effect of Fiscal Performance on Local Government Election Results in Israel: 1989-1998,” Journal of Public Economics 87, 2187-2205.

Brender, A. and A. Drazen (2005a), "Political Budget Cycles in New Versus Established Democracies," Journal of Monetary Economics 52 (7), 1271-1295.

(2005b), "How Do Budget Deficits and Economic Growth Affect Reelection Prospects?

Evidence from a Large Cross-Section of Countries,” NBER Working Paper 11862.

(2007), "Why is Economic Policy Different in New Democracies? Affecting Attitudes About Democracy,” NBER working paper 13457.

Drazen, A. (2001), Political Business Cycle after 25 Years, in B. Bernanke and K. Rogoff, eds. NBER Macroeconomics Annual 2000, Cambridge, MA: MIT Press, 75-117.

Drazen, A. and M. Eslava (2007), "Electoral Manipulation via Voter-Friendly Spending: Theory and Evidence,” working paper. (Earlier version circulated as NBER Working Paper 11085).

(2006), “Pork Barrel Cycles,” NBER Working Paper 12190.

Fair, R. (1978), “The Effect of Economic Events on Votes for President,” Review of Economics and Statistics 60, 159-72.

Faust, J. and J. Irons (1999), “Money, Politics, and the Post-War Business Cycle,” Journal of Monetary Economics 43, 61-89.

Giavazzi, F and M. Pagano (1990), "Can Severe Fiscal Adjustment Be Expansionary? Tales of Two Small European Countries." In NBER Macroeconomics Annual 1990, ed.O. Blanchard and S. Fischer. MIT Press.

Inglehart, R., et al. (2004), “World Values Surveys and European Values Surveys, 1999-2001, ” Ann Arbor, MI: Inter-university Consortium for Political and Social Research. 
Leigh, A. (2004), “Does the World Economy Swing National Elections?,” Discussion Paper 485, Economics Program, Research School of Social Sciences, The Australian National University.

Lewis-Beck, M. (1988), Economics and Elections: The Major Western Democracies, Ann Arbor: University of Michigan Press.

Maddala, G.S and S. Wu (1999), "A Comparative Study Of Unit root Tests With Panel Data and a New Simple Test," Oxford Bulletin of Economics and Statistics 61, 631-52.

Nordhaus, W. (1975), “The Political Business Cycle,” Review of Economic Studies 42, 169-90.

(1989), “Alternative Approaches to the Political Business Cycle,” Brookings Papers in Economic Activity 2, 1989, 1-49.

Paldam, M. (1979) "Is There An Electoral Cycle? A Comparative Study of National Accounts,” Scandinavian Journal of Economics 81, 323-42.

(1991), "How Robust is the Vote Function? A Study of Seventeen Nations Over Four Decades," in H. Norpoth, M.S. Lewis-Beck and J.D. Lafay, eds., Economics and Politics: The Calculus of Support, Ann Arbor: University of Michigan Press.

Peltzman, S. (1992), “Voters as Fiscal Conservatives,” Quarterly Journal of Economics 107, 327-261.

Persson, T. and G. Tabellini (1990), Macroeconomic Policy, Credibility, and Politics, London: Harwood. (2003), The Economic Effect of Constitutions: What Do the Data Say?, Cambridge, MA: MIT Press.

Powell, Jr., G. B., and G. Whitten (1993), “A Cross-National Analysis of Economic Voting: Taking Account of the Political Context,” American Journal of Political Science 37: 391-414.

Rogoff, K. (1990), “Equilibrium Political Budget Cycles,” American Economic Review 80, 21-36.

Rogoff, K. and A. Sibert (1988), "Elections and Macroeconomic Policy Cycles,” Review of Economic Studies 55, 1-16.

Roubini N. and J. Sachs (1989), "Political and Economic Determinants of Budget Deficits in the Industrial Democracies,” European Economic Review 33, 903-38.

Shi, M. and J. Svensson (2006), “Political Budget Cycles: Do They Differ Across Countries and Why?,” Journal of Public Economics 90, 1367-89.

Shiller R.J. (1996), "Why Do People Dislike Inflation?, ” NBER working paper 5539.

Strøm, K. and S. M. Lipset (1984), "Macroeconomics and Macropolitics: The Electoral Performance of Democratic Governments," Paper presented at the Annual Meeting of the American Political Science Association, Washington, D.C.

Tavares J. (2004), "Does Right or Left Matter? Cabinets, Credibility and Fiscal Adjustments," Journal of Public Economics 88, 2447-68.

Zárate, R.O. (2005), Zárate's Political Collections (ZPC) 1996-2005. 
Table 1: Descriptive Statistics

\begin{tabular}{|c|c|c|c|c|c|c|c|c|c|}
\hline & \multicolumn{3}{|c|}{ All Countries } & \multicolumn{3}{|c|}{ Developed Countries } & \multicolumn{3}{|c|}{ Developing Countries } \\
\hline & All & Reelect $=1$ & Reelect $=0$ & All & Reelect=1 & Reelect $=0$ & All & Reelect $=1$ & Reelect $=0$ \\
\hline \multicolumn{10}{|l|}{ Narrow Sample } \\
\hline \multirow{2}{*}{$\begin{array}{l}\text { Observations } \\
\text { of which Established }\end{array}$} & 255 & 126 & 129 & 164 & 86 & 78 & 91 & 40 & 51 \\
\hline & 194 & 95 & 99 & 153 & 79 & 74 & 41 & 16 & 25 \\
\hline \multicolumn{10}{|l|}{ Expanded Sample } \\
\hline \multirow{2}{*}{$\begin{array}{l}\text { Observations } \\
\text { of which Established }\end{array}$} & 347 & 147 & 200 & 180 & 88 & 92 & 167 & 59 & 108 \\
\hline & 241 & 106 & 135 & 169 & 81 & 88 & 72 & 25 & 47 \\
\hline \multirow{2}{*}{$\begin{array}{rc}\text { BALCH_term } & \text { mean } \\
& \text { standard deviation }\end{array}$} & 0.017 & 0.261 & -0.162 & 0.060 & 0.268 & -0.140 & -0.028 & 0.251 & -0.180 \\
\hline & 2.372 & 2.224 & 2.466 & 2.214 & 2.183 & 2.237 & 2.538 & 2.303 & 2.656 \\
\hline \multirow[t]{2}{*}{ BALCH_ey $^{1} \quad$ mean } & -0.338 & -0.084 & -0.525 & -0.164 & 0.232 & -0.543 & -0.526 & -0.556 & -0.509 \\
\hline & 1.883 & 1.811 & 1.918 & 1.699 & 1.424 & 1.855 & 2.052 & 2.198 & 1.978 \\
\hline \multirow[t]{2}{*}{ GDPPC_gr ${ }^{1}$} & 2.317 & 2.842 & 1.932 & 2.532 & 2.685 & 2.385 & 2.086 & 3.075 & 1.546 \\
\hline & 2.106 & 1.768 & 2.251 & 1.781 & 1.608 & 1.930 & 2.392 & 1.973 & 2.435 \\
\hline \multirow{2}{*}{$\begin{array}{r}\text { GDPPC_gr_ey }^{2} \\
\text { standard deviation }\end{array}$} & 2.408 & 2.799 & 2.121 & 2.750 & 3.056 & 2.456 & 2.041 & 2.416 & 1.836 \\
\hline & 3.081 & 2.583 & 3.378 & 2.457 & 1.983 & 2.817 & 3.607 & 3.263 & 3.781 \\
\hline \multirow{2}{*}{$\begin{array}{lc}\text { INFCH_ey }^{3} & \begin{array}{c}\text { mean } \\
\text { standard deviation }\end{array}\end{array}$} & -0.157 & -0.786 & 0.304 & 0.014 & -0.442 & 0.451 & -0.343 & -1.299 & 0.180 \\
\hline & 10.232 & 3.920 & 13.048 & 4.331 & 2.500 & 5.525 & 14.068 & 5.372 & 17.047 \\
\hline \multirow{2}{*}{$\begin{array}{cc}\text { Average_INF } & \text { mean } \\
\text { standard deviation }\end{array}$} & 12.980 & 9.632 & 15.440 & 8.322 & 6.802 & 9.777 & 17.999 & 13.853 & 20.265 \\
\hline & 17.305 & 14.138 & 18.965 & 11.802 & 11.231 & 12.207 & 20.618 & 16.843 & 22.160 \\
\hline
\end{tabular}

${ }^{1}$ BALCH_term - The change in the ratio of the government deficit to GDP in the two years preceding the election year, relative to the two previous yearsBALCH_ey -The change in the government deficit ratio to GDP In the election year, compared to the previous year.GDPPC gr - The average growth rate of real per-capita GDP during the leader's current term.

${ }^{2}$ GDPPC_gr_ey - Per-capita GDP growth in the last year of the leader's term.

${ }^{3}$ INFCH_ey - The increase in the inflation rate from the year preceding the election year to the election year.

${ }^{4}$ Average_INF - The average annual rate of inflation during the leader's current term. 
Table 2: The Effects of Budget Balances and Growth on the Probability of Reelection in Developed and Less Developed Economies $^{1}$

\begin{tabular}{|c|c|c|c|c|c|c|}
\hline \multirow{4}{*}{ Dependent variable: REELECT } & \multicolumn{3}{|c|}{ Narrow Sample } & \multicolumn{3}{|c|}{ Expanded Sample } \\
\hline & (1) & (2) & (3) & (4) & (5) & (6) \\
\hline & & & |Less & & & Less \\
\hline & All Countries & Developed & Developed & All Countries & Developed & Developed \\
\hline BALCH_term ${ }^{2}$ & $\begin{array}{l}14.171^{\star *} \\
{[0.027]}\end{array}$ & $\begin{array}{l}20.036^{\star *} \\
{[0.017]}\end{array}$ & $\begin{array}{l}15.835 \\
{[0.188]}\end{array}$ & $\begin{array}{l}10.576^{* *} \\
{[0.036]}\end{array}$ & $\begin{array}{l}13.225^{\star} \\
{[0.096]}\end{array}$ & $\begin{array}{l}13.483^{\star} \\
{[0.060]}\end{array}$ \\
\hline BALCH_ey ${ }^{2}$ & $\begin{array}{l}14.413^{*} \\
{[0.088]}\end{array}$ & $\begin{array}{l}39.846^{\star \star \star} \\
{[0.001]}\end{array}$ & $\begin{array}{l}-3.451 \\
{[0.773]}\end{array}$ & $\begin{array}{l}11.777^{*} \\
{[0.098]}\end{array}$ & $\begin{array}{l}35.188^{\star \star \star} \\
{[0.001]}\end{array}$ & $\begin{array}{l}1.210 \\
{[0.902]}\end{array}$ \\
\hline GDPPC_gr ${ }^{2}$ & $\begin{array}{l}17.017^{\star \star} \\
{[0.012]}\end{array}$ & $\begin{array}{l}-5.684 \\
{[0.560]}\end{array}$ & $\begin{array}{l}37.068^{\star \star \star} \\
{[0.001]}\end{array}$ & $\begin{array}{l}21.355^{\star \star \star} \\
{[0.000]}\end{array}$ & $\begin{array}{l}-0.755 \\
{[0.937]}\end{array}$ & $\begin{array}{l}34.468^{\star \star \star} \\
{[0.000]}\end{array}$ \\
\hline Developed Countries & $\begin{array}{l}0.822^{\star *} \\
{[0.024]}\end{array}$ & & & $\begin{array}{l}0.705^{\star \star} \\
{[0.014]}\end{array}$ & & \\
\hline New Democracies & $\begin{array}{l}0.683^{*} \\
{[0.069]}\end{array}$ & $\begin{array}{l}1.189^{\star \star} \\
{[0.046]}\end{array}$ & $\begin{array}{l}0.601 \\
{[0.229]}\end{array}$ & $\begin{array}{l}0.341 \\
{[0.261]}\end{array}$ & $\begin{array}{l}1.266^{\star \star} \\
{[0.033]}\end{array}$ & $\begin{array}{l}0.191 \\
{[0.591]}\end{array}$ \\
\hline Majoritarian Electoral System & $\begin{array}{l}0.768^{\star *} \\
{[0.015]}\end{array}$ & $\begin{array}{l}0.694 \\
{[0.136]}\end{array}$ & $\begin{array}{l}0.779 \\
{[0.106]}\end{array}$ & $\begin{array}{l}0.715^{\star \star \star} \\
{[0.006]}\end{array}$ & $\begin{array}{l}0.586 \\
{[0.142]}\end{array}$ & $\begin{array}{l}0.703^{\star} \\
{[0.059]}\end{array}$ \\
\hline Constant & $\begin{array}{l}-1.328^{\star \star \star} \\
{[0.001]}\end{array}$ & $\begin{array}{l}0.101 \\
{[0.750]}\end{array}$ & $\begin{array}{l}-1.923^{\star \star \star} \\
{[0.000]}\end{array}$ & $\begin{array}{l}-1.455^{\star \star \star} \\
{[0.000]}\end{array}$ & $\begin{array}{l}-0.182 \\
{[0.555]}\end{array}$ & $\begin{array}{l}-1.739 \star \star \star \\
{[0.000]}\end{array}$ \\
\hline Pseudo $\mathrm{R}^{2}$ & 0.067 & 0.085 & 0.128 & 0.075 & 0.071 & 0.112 \\
\hline LR(chi2) & 20.01 & 15.73 & 15.64 & 31.61 & 15.35 & 21.22 \\
\hline Akaike's criteria & 343.71 & 219.60 & 120.79 & 451.31 & 243.81 & 204.66 \\
\hline Schwartz's criteria & 368.50 & 238.20 & 135.86 & 478.25 & 262.97 & 223.37 \\
\hline Observations & 255 & 164 & 91 & 347 & 180 & 167 \\
\hline
\end{tabular}

${ }^{1}$ For variables definitions see the statistical Appendix. The figures in the table are logit coefficients and the figures in the parantheses are Pvalues calculated on the basis of robust standard errors.

${ }^{2}$ BALCH_term - The change in the ratio of the government deficit to GDP in the two years preceding the election year, relative to the two previous years. BALCH_ey -The change in the government deficit ratio to GDP In the election year, compared to the previous year. GDPPC_gr - The average growth rate of real per-capita GDP during the leader's current term.

* - Significant at the 10 percent level; ** - Significant at the 5 percent level; ** - Significant at the 1 percent level. 
Table 3: The Effects of Budget Balances and Growth on the Probability of Reelection in Developed and Less Developed Economies $^{1}$

\begin{tabular}{|c|c|c|c|c|c|c|c|c|}
\hline \multirow{3}{*}{$\begin{array}{l}\text { Dependent variable: } \\
\text { REELECT }\end{array}$} & \multicolumn{4}{|c|}{ Narrow Sample } & \multicolumn{4}{|c|}{ Expanded Sample } \\
\hline & \multicolumn{2}{|c|}{ Developed } & \multicolumn{2}{|c|}{ Less Developed } & \multicolumn{2}{|c|}{ Developed } & \multicolumn{2}{|c|}{ Less Developed } \\
\hline & Logit & $\begin{array}{l}\text { Fixed } \\
\text { effects }\end{array}$ & Logit & $\begin{array}{l}\text { Fixed } \\
\text { effects }\end{array}$ & Logit & $\begin{array}{l}\text { Fixed } \\
\text { effects }\end{array}$ & Logit & $\begin{array}{l}\text { Fixed } \\
\text { effects }\end{array}$ \\
\hline BALCH_term ${ }^{2}$ & $\begin{array}{l}19.974^{\star \star} \\
{[0.017]}\end{array}$ & $\begin{array}{l}16.672^{\star} \\
{[0.069]}\end{array}$ & $\begin{array}{c}17.475 \\
{[0.317]}\end{array}$ & $\begin{array}{l}10.118 \\
{[0.627]}\end{array}$ & $\begin{array}{l}13.044^{*} \\
{[0.100]}\end{array}$ & $\begin{array}{l}11.703 \\
{[0.146]}\end{array}$ & $\begin{array}{l}15.696^{*} \\
{[0.083]}\end{array}$ & $\begin{array}{l}14.939 \\
{[0.125]}\end{array}$ \\
\hline BALCH_ey ${ }^{2}$ & $\begin{array}{l}36.879 \star \star \star \\
{[0.003]}\end{array}$ & $\begin{array}{l}30.258^{\star \star} \\
{[0.025]}\end{array}$ & $\begin{array}{l}0.032 \\
{[0.998]}\end{array}$ & $\begin{array}{l}21.819 \\
{[0.237]}\end{array}$ & $\begin{array}{l}32.568^{\star \star \star} \\
{[0.004]}\end{array}$ & $\begin{array}{l}29.742^{\star \star} \\
{[0.016]}\end{array}$ & $\begin{array}{l}1.675 \\
{[0.872]}\end{array}$ & $\begin{array}{l}7.902 \\
{[0.467]}\end{array}$ \\
\hline GDPPC_gr ${ }^{2}$ & $\begin{array}{l}-1.595 \\
{[0.874]}\end{array}$ & $\begin{array}{l}8.247 \\
{[0.483]}\end{array}$ & $\begin{array}{l}37.213^{\star \star} \\
{[0.012]}\end{array}$ & $\begin{array}{l}53.110^{\star \star} \\
{[0.046]}\end{array}$ & $\begin{array}{l}3.053 \\
{[0.756]}\end{array}$ & $\begin{array}{l}13.602 \\
{[0.229]}\end{array}$ & $\begin{array}{l}31.946^{\star \star \star} \\
{[0.001]}\end{array}$ & $\begin{array}{l}31.566^{\star \star} \\
{[0.015]}\end{array}$ \\
\hline New Democracies & $\begin{array}{l}1.052^{\star} \\
{[0.084]}\end{array}$ & $\begin{array}{l}2.268 \\
{[0.106]}\end{array}$ & $\begin{array}{l}0.966 \\
{[0.107]}\end{array}$ & $\begin{array}{l}1.872 \\
{[0.995]}\end{array}$ & $\begin{array}{l}1.147^{\star} \\
{[0.058]}\end{array}$ & $\begin{array}{l}2.580 * \\
{[0.070]}\end{array}$ & $\begin{array}{l}0.787^{\star *} \\
{[0.046]}\end{array}$ & $\begin{array}{l}2.775^{\star \star} \\
{[0.019]}\end{array}$ \\
\hline $\begin{array}{l}\text { Majoritarian Electoral } \\
\text { System }\end{array}$ & $\begin{array}{l}0.610 \\
{[0.190]}\end{array}$ & $\begin{array}{l}2.004 \\
{[0.129]}\end{array}$ & $\begin{array}{l}0.388 \\
{[0.526]}\end{array}$ & $\begin{array}{l}-33.670 \\
{[0.995]}\end{array}$ & $\begin{array}{l}0.513 \\
{[0.198]}\end{array}$ & $\begin{array}{l}1.266 \\
{[0.265]}\end{array}$ & $\begin{array}{l}0.244 \\
{[0.539]}\end{array}$ & $\begin{array}{l}-15.171 \\
{[0.990]}\end{array}$ \\
\hline Constant & $\begin{array}{l}0.096 \\
{[0.765]}\end{array}$ & & $\begin{array}{l}-1.834^{\star \star \star} \\
{[0.003]}\end{array}$ & & $\begin{array}{l}-0.192 \\
{[0.541]}\end{array}$ & & $\begin{array}{l}-1.397^{\star * *} \\
{[0.000]}\end{array}$ & \\
\hline Pseudo $\mathbf{R}^{2}$ & 0.077 & 0.107 & 0.122 & 0.312 & 0.064 & 0.098 & 0.104 & 0.175 \\
\hline \multirow[t]{2}{*}{ Hausman test } & \multicolumn{2}{|c|}{8.86} & \multicolumn{2}{|c|}{4.17} & \multicolumn{2}{|c|}{5.46} & \multicolumn{2}{|c|}{7.07} \\
\hline & \multicolumn{2}{|c|}{ [0.115] } & \multicolumn{2}{|c|}{ [0.526] } & \multicolumn{2}{|c|}{ [0.363] } & \multicolumn{2}{|c|}{ [0.216] } \\
\hline Observations & 157 & 157 & 59 & 59 & 173 & 173 & 125 & 125 \\
\hline
\end{tabular}

${ }^{1}$ For variables definitions see the statistical Appendix. The figures in the table are logit coefficients and the figures in the parantheses are Pvalues.

${ }^{2}$ BALCH_term - The change in the ratio of the government deficit to GDP in the two years preceding the election year, relative to the two previous years. BALCH_ey -The change in the government deficit ratio to GDP In the election year, compared to the previous year. GDPPC_gr The average growth rate of real per-capita GDP during the leader's current term.

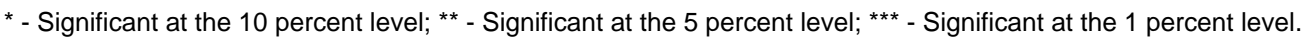


Table 4: Additional Effects of Election Year Budget Balances and Growth on the Probability of Reelection ${ }^{1}$

\begin{tabular}{|c|c|c|c|c|c|c|c|c|}
\hline \multirow{2}{*}{ Dependent variable: REELECT } & \multicolumn{5}{|c|}{ Narrow Sample } & \multicolumn{3}{|c|}{ Expanded Sample } \\
\hline & (1) & (2) & (3) & (4) & (5) & (6) & (7) & (8) \\
\hline BALCH_term * devloped ${ }^{2}$ & $\begin{array}{l}19.592^{\star \star} \\
{[0.017]}\end{array}$ & $\begin{array}{l}19.897^{\star *} \\
{[0.017]}\end{array}$ & $\begin{array}{l}20.433^{\star \star} \\
{[0.013]}\end{array}$ & & $\begin{array}{l}17.653^{*} \\
{[0.084]}\end{array}$ & $\begin{array}{l}12.496 \\
{[0.102]}\end{array}$ & & $\begin{array}{l}11.864 \\
{[0.206]}\end{array}$ \\
\hline BALCH_term * less_developed ${ }^{2}$ & $\begin{array}{l}14.835 \\
{[0.221]}\end{array}$ & $\begin{array}{l}13.274 \\
{[0.293]}\end{array}$ & $\begin{array}{l}11.352 \\
{[0.359]}\end{array}$ & & $\begin{array}{l}11.227 \\
{[0.414]}\end{array}$ & $\begin{array}{l}13.588^{*} \\
{[0.062]}\end{array}$ & & $\begin{array}{l}11.301 \\
{[0.141]}\end{array}$ \\
\hline BALCH_ey * developed ${ }^{2}$ & $\begin{array}{l}38.432^{\star \star \star} \\
{[0.001]}\end{array}$ & $\begin{array}{l}38.334^{\star \star \star} \\
{[0.001]}\end{array}$ & $\begin{array}{l}34.315^{\star \star \star} \\
{[0.006]}\end{array}$ & $\begin{array}{l}32.262^{\star \star \star} \\
{[0.003]}\end{array}$ & $\begin{array}{l}39.741^{\star \star \star} \\
{[0.002]}\end{array}$ & $\begin{array}{l}32.527^{\star \star \star} \\
{[0.002]}\end{array}$ & $\begin{array}{l}28.229^{\star \star \star} \\
{[0.005]}\end{array}$ & $\begin{array}{l}34.019^{\star \star \star \star} \\
{[0.006]}\end{array}$ \\
\hline BALCH_ey * less_developed ${ }^{2}$ & $\begin{array}{l}-2.623 \\
{[0.834]}\end{array}$ & $\begin{array}{l}-0.946 \\
{[0.940]}\end{array}$ & $\begin{array}{l}-0.931 \\
{[0.943]}\end{array}$ & $\begin{array}{l}-6.486 \\
{[0.594]}\end{array}$ & $\begin{array}{l}14.326 \\
{[0.473]}\end{array}$ & $\begin{array}{l}0.847 \\
{[0.931]}\end{array}$ & $\begin{array}{l}-3.539 \\
{[0.706]}\end{array}$ & $\begin{array}{l}8.793 \\
{[0.504]}\end{array}$ \\
\hline GDPPC_gr * developed ${ }^{2}$ & $\begin{array}{l}-5.291 \\
{[0.583]}\end{array}$ & $\begin{array}{l}-6.326 \\
{[0.619]}\end{array}$ & $\begin{array}{l}-8.888 \\
{[0.392]}\end{array}$ & $\begin{array}{l}-8.225 \\
{[0.403]}\end{array}$ & $\begin{array}{l}-5.155 \\
{[0.592]}\end{array}$ & $\begin{array}{l}0.071 \\
{[0.994]}\end{array}$ & $\begin{array}{l}-2.370 \\
{[0.802]}\end{array}$ & $\begin{array}{l}-0.025 \\
{[0.998]}\end{array}$ \\
\hline GDPPC_gr * less_developed ${ }^{2}$ & $\begin{array}{l}38.370^{\star \star \star} \\
{[0.000]}\end{array}$ & $\begin{array}{l}59.669^{\star \star \star} \\
{[0.000]}\end{array}$ & $\begin{array}{l}51.084^{\star \star \star} \\
{[0.000]}\end{array}$ & $\begin{array}{l}36.953^{\star \star \star} \\
{[0.001]}\end{array}$ & $\begin{array}{l}39.471^{\star \star \star} \\
{[0.001]}\end{array}$ & $\begin{array}{l}34.794^{\star \star \star} \\
{[0.000]}\end{array}$ & $\begin{array}{l}32.488^{\star \star \star} \\
{[0.000]}\end{array}$ & $\begin{array}{l}34.462^{\star \star \star} \\
{[0.000]}\end{array}$ \\
\hline GDPPC_gr_ey * developed ${ }^{3}$ & & $\begin{array}{l}1.287 \\
{[0.893]}\end{array}$ & & & & & & \\
\hline GDPPC_gr_ey * less_developed ${ }^{3}$ & & $\begin{array}{l}-21.071^{\star \star \star} \\
{[0.008]}\end{array}$ & & & & & & \\
\hline GDPD_trend_ey * developed ${ }^{4}$ & & & $\begin{array}{l}10.992 \\
{[0.289]}\end{array}$ & & & & & \\
\hline GDPD_trend_ey * less_developed ${ }^{4}$ & & & $\begin{array}{l}-27.553^{\star \star \star} \\
{[0.001]}\end{array}$ & & & & & \\
\hline BALCH_term+ey * developed ${ }^{5}$ & & & & $\begin{array}{l}22.722^{\star \star \star} \\
{[0.001]}\end{array}$ & & & $\begin{array}{l}16.703^{* *} \\
{[0.012]}\end{array}$ & \\
\hline BALCH_term+ey * less_developed ${ }^{5}$ & & & & $\begin{array}{l}10.445 \\
{[0.344]}\end{array}$ & & & $\begin{array}{l}9.673 \\
{[0.196]}\end{array}$ & \\
\hline BALCH_term ${ }^{*}$ Def_Size ${ }^{*}$ developed ${ }^{6}$ & & & & & $\begin{array}{l}-0.664 \\
{[0.716]}\end{array}$ & & & $\begin{array}{l}-0.205 \\
{[0.900]}\end{array}$ \\
\hline BALCH_term * Def_Size * less_developed ${ }^{6}$ & & & & & $\begin{array}{l}0.319 \\
{[0.823]}\end{array}$ & & & $\begin{array}{l}-0.204 \\
{[0.848]}\end{array}$ \\
\hline BALCH_ey * Def_Size * developed ${ }^{6}$ & & & & & $\begin{array}{l}0.321 \\
{[0.886]}\end{array}$ & & & $\begin{array}{l}0.458 \\
{[0.821]}\end{array}$ \\
\hline BALCH_ey * Def_Size * less_developed ${ }^{6}$ & & & & & $\begin{array}{l}3.491 \\
{[0.274]}\end{array}$ & & & $\begin{array}{l}1.748 \\
{[0.445]}\end{array}$ \\
\hline Developed Countries & $\begin{array}{l}2.181^{\star \star \star} \\
{[0.000]}\end{array}$ & $\begin{array}{l}2.262^{\star \star \star} \\
{[0.000]}\end{array}$ & $\begin{array}{l}2.645^{\star \star \star} \\
{[0.000]}\end{array}$ & $\begin{array}{l}2.247^{\star \star \star} \\
{[0.000]}\end{array}$ & $\begin{array}{l}2.200^{\star \star \star} \\
{[0.000]}\end{array}$ & $\begin{array}{l}1.692^{\star \star \star} \\
{[0.000]}\end{array}$ & $\begin{array}{l}1.743^{\star \star \star} \\
{[0.000]}\end{array}$ & $\begin{array}{l}1.696^{\star \star \star} \\
{[0.000]}\end{array}$ \\
\hline New Democracies & $\begin{array}{l}0.825^{\star \star} \\
{[0.034]}\end{array}$ & $\begin{array}{l}0.945^{\star *} \\
{[0.021]}\end{array}$ & $\begin{array}{l}1.034^{\star \star} \\
{[0.014]}\end{array}$ & $\begin{array}{l}0.833^{\star \star} \\
{[0.032]}\end{array}$ & $\begin{array}{l}0.860^{\star *} \\
{[0.030]}\end{array}$ & $\begin{array}{l}0.420 \\
{[0.177]}\end{array}$ & $\begin{array}{l}0.437 \\
{[0.161]}\end{array}$ & $\begin{array}{l}0.436 \\
{[0.170]}\end{array}$ \\
\hline Majoritarian Electoral System & $\begin{array}{l}0.711^{\star \star} \\
{[0.035]}\end{array}$ & $\begin{array}{l}0.748^{\star \star} \\
{[0.027]}\end{array}$ & $\begin{array}{l}0.689^{\star \star} \\
{[0.044]}\end{array}$ & $\begin{array}{l}0.734^{\star \star} \\
{[0.031]}\end{array}$ & $\begin{array}{l}0.761^{\star \star} \\
{[0.026]}\end{array}$ & $\begin{array}{l}0.626^{\star \star} \\
{[0.022]}\end{array}$ & $\begin{array}{l}0.644^{\star \star} \\
{[0.019]}\end{array}$ & $\begin{array}{l}0.631^{\star *} \\
{[0.021]}\end{array}$ \\
\hline Constant & $\begin{array}{l}-2.072^{\star \star \star} \\
{[0.000]}\end{array}$ & $\begin{array}{l}-2.178^{\star \star \star} \\
{[0.000]}\end{array}$ & $\begin{array}{l}-2.496^{\star \star \star} \\
{[0.000]}\end{array}$ & $\begin{array}{l}-2.043^{\star \star \star} \\
{[0.000]}\end{array}$ & $\begin{array}{l}-2.113^{\star \star *} \\
{[0.000]}\end{array}$ & $\begin{array}{l}-1.857^{\star \star \star} \\
{[0.000]}\end{array}$ & $\begin{array}{l}-1.835^{\star \star \star} \\
{[0.000]}\end{array}$ & $\begin{array}{l}-1.861^{\star \star \star} \\
{[0.000]}\end{array}$ \\
\hline Pseudo $^{2}$ & 0.104 & 0.122 & 0.138 & 0.113 & 0.108 & 0.098 & 0.102 & 0.101 \\
\hline LR(chi2) & 34.23 & 39.51 & 44.35 & 36.63 & 34.26 & 40.79 & 41.21 & 40.22 \\
\hline Akaike's criteria & 334.18 & 331.89 & 326.23 & 330.90 & 448.33 & 446.53 & 444.82 & 453.37 \\
\hline Schwartz's criteria & 369.52 & 374.29 & 368.63 & 366.23 & 490.68 & 485.02 & 483.31 & 507.26 \\
\hline Observations & 253 & 253 & 253 & 253 & 253 & 347 & 347 & 347 \\
\hline
\end{tabular}

${ }^{1}$ For variables definitions see the text section of the appendix. The figures in the table are logit coefficients and the figures in the parantheses are P-values calculated on the basis of robust standard errors. An asterisk (*) indicates multiplication by the binary variable that follows. developed - A binary variable with a value of 1 for developed countries, less_developed - A binary variable with a value of 1 for less developed countries.

${ }^{2}$ BALCH_term - The change in the ratio of the government deficit to GDP in the two years preceding the election year, relative to the two previous years.BALCH_ey -The change in the government deficit ratio to GDP In the election year, compared to the previous year. GDPPC_gr - The average growth rate of real per-capita GDP during the leader's current term.

${ }^{3}$ GDPPC_gr_ey - Per-capita GDP growth in the last year of the leader's term.

${ }^{4}$ GDPD_trend_ey - The change in the deviation of real GDP from its trend, estimated using a Hodrick-Prescott filter, in the last year of the leader's term.

${ }^{5}$ BALCH_term+ey - The change in the budget balance ratio to GDP during the leader's term, including elections year.

${ }^{6}$ Def_Size - The budget deficit ratio to GDP at the beginning of the leader's term. An asterisk $\left(^{*}\right)$ indicates multiplication by this variable.

* - Significant at the 10 percent level; ** - Significant at the 5 percent level; *** - Significant at the 1 percent level. 
Table 5: The Effects of Budget Balances, Growth and Deviations of GDP from its trend on the Probability of Reelection in Developed, Less Developed and New Democracies ${ }^{1}$

\begin{tabular}{|c|c|c|c|c|}
\hline \multirow{2}{*}{ Dependent variable: REELECT } & \multicolumn{2}{|c|}{ Narrow Sample } & \multicolumn{2}{|c|}{ Expanded Sample } \\
\hline & (1) & $(2)$ & (3) & (4) \\
\hline BALCH_term * old_developed ${ }^{2}$ & $\begin{array}{l}19.620^{\star \star} \\
{[0.016]}\end{array}$ & $\begin{array}{l}20.032^{\star \star} \\
{[0.013]}\end{array}$ & $\begin{array}{l}13.313^{*} \\
{[0.085]}\end{array}$ & $\begin{array}{l}13.850^{\star} \\
{[0.073]}\end{array}$ \\
\hline BALCH_term * old_less_developed ${ }^{2}$ & $\begin{array}{l}8.874 \\
{[0.533]}\end{array}$ & $\begin{array}{l}8.879 \\
{[0.541]}\end{array}$ & $\begin{array}{l}14.715 \\
{[0.113]}\end{array}$ & $\begin{array}{l}14.975 \\
{[0.110]}\end{array}$ \\
\hline BALCH_term * new_democracy ${ }^{2}$ & $\begin{array}{l}-0.298 \\
{[0.987]}\end{array}$ & $\begin{array}{l}-0.823 \\
{[0.968]}\end{array}$ & $\begin{array}{l}7.683 \\
{[0.425]}\end{array}$ & $\begin{array}{l}10.552 \\
{[0.316]}\end{array}$ \\
\hline BALCH_ey *old_developed ${ }^{2}$ & $\begin{array}{l}32.280^{\star \star \star} \\
{[0.006]}\end{array}$ & $\begin{array}{l}27.504^{\star \star} \\
{[0.039]}\end{array}$ & $\begin{array}{l}28.985^{\star \star \star} \\
{[0.008]}\end{array}$ & $\begin{array}{l}25.424^{\star *} \\
{[0.039]}\end{array}$ \\
\hline BALCH_ey * old_less_developed ${ }^{2}$ & $\begin{array}{l}-15.075 \\
{[0.416]}\end{array}$ & $\begin{array}{l}-14.898 \\
{[0.444]}\end{array}$ & $\begin{array}{l}6.204 \\
{[0.655]}\end{array}$ & $\begin{array}{l}5.349 \\
{[0.703]}\end{array}$ \\
\hline BALCH_ey * new_democracy ${ }^{2}$ & $\begin{array}{l}17.028 \\
{[0.369]}\end{array}$ & $\begin{array}{l}17.945 \\
{[0.374]}\end{array}$ & $\begin{array}{l}7.150 \\
{[0.582]}\end{array}$ & $\begin{array}{l}11.035 \\
{[0.438]}\end{array}$ \\
\hline GDPPC_gr* old_developed ${ }^{2}$ & $\begin{array}{l}-2.654 \\
{[0.783]}\end{array}$ & $\begin{array}{l}-6.460 \\
{[0.545]}\end{array}$ & $\begin{array}{l}0.920 \\
{[0.921]}\end{array}$ & $\begin{array}{l}-2.399 \\
{[0.813]}\end{array}$ \\
\hline GDPPC_gr * old_less_developed ${ }^{2}$ & $\begin{array}{l}24.878^{\star \star} \\
{[0.048]}\end{array}$ & $\begin{array}{l}25.140 * \\
{[0.057]}\end{array}$ & $\begin{array}{l}32.268^{\star \star \star} \\
{[0.002]}\end{array}$ & $\begin{array}{l}32.178^{\star \star \star} \\
{[0.003]}\end{array}$ \\
\hline GDPPC_gr * new_democracy ${ }^{2}$ & $\begin{array}{l}41.302^{\star \star \star} \\
{[0.001]}\end{array}$ & $\begin{array}{l}45.944^{\star \star \star} \\
{[0.001]}\end{array}$ & $\begin{array}{l}33.986^{\star \star \star} \\
{[0.000]}\end{array}$ & $\begin{array}{l}38.580^{\star \star \star} \\
{[0.000]}\end{array}$ \\
\hline GDPD_trend_ey * old_developed ${ }^{3}$ & & $\begin{array}{l}9.159 \\
{[0.408]}\end{array}$ & & $\begin{array}{l}7.572 \\
{[0.475]}\end{array}$ \\
\hline GDPD_trend_ey * old_less_developed ${ }^{3}$ & & $\begin{array}{l}-0.940 \\
{[0.948]}\end{array}$ & & $\begin{array}{l}1.270 \\
{[0.916]}\end{array}$ \\
\hline GDPD_trend_ey * new_democracy ${ }^{3}$ & & $\begin{array}{l}-21.214^{\star \star} \\
{[0.015]}\end{array}$ & & $\begin{array}{l}-17.623^{\star \star \star} \\
{[0.009]}\end{array}$ \\
\hline Developed Countries & $\begin{array}{l}1.415^{\star \star \star} \\
{[0.002]}\end{array}$ & $\begin{array}{l}1.484^{\star \star \star} \\
{[0.002]}\end{array}$ & $\begin{array}{l}1.328^{\star \star *} \\
{[0.000]}\end{array}$ & $\begin{array}{l}1.390 \star \star \star \\
{[0.000]}\end{array}$ \\
\hline Majoritarian Electoral System & $\begin{array}{l}0.670^{\star *} \\
{[0.038]}\end{array}$ & $\begin{array}{l}0.620^{\star} \\
{[0.055]}\end{array}$ & $\begin{array}{l}0.614^{\star *} \\
{[0.022]}\end{array}$ & $\begin{array}{l}0.530^{\star} \\
{[0.052]}\end{array}$ \\
\hline Constant & $\begin{array}{l}-1.401^{\star \star \star} \\
{[0.000]}\end{array}$ & $\begin{array}{l}-1.385^{\star \star \star} \\
{[0.001]}\end{array}$ & $\begin{array}{l}-1.555^{\star \star \star} \\
{[0.000]}\end{array}$ & $\begin{array}{l}-1.532^{\star \star \star} \\
{[0.000]}\end{array}$ \\
\hline Pseudo $\mathrm{R}^{2}$ & 0.095 & 0.113 & 0.093 & 0.107 \\
\hline LR(chi2) & 27.446 & 30.440 & 38.349 & 42.753 \\
\hline Akaike's criteria & 341.55 & 341.21 & 450.38 & 449.74 \\
\hline Schwartz's criteria & 383.95 & 394.21 & 496.50 & 507.40 \\
\hline Observations & 253 & 253 & 345 & 345 \\
\hline
\end{tabular}

${ }^{1}$ For variables definitions see the statistical appendix. The figures in the table are logit coefficients and the figures in the parantheses are P-values calculated on the basis of robust standard errors. An asterisk $\left({ }^{*}\right)$ indicates multiplication by the binary variable that follows. new_democracy - A binary variable with a value of 1 for new democracies, old_developed - A binary variable with a value of 1 for old and developed democracies, old_less_developed - A binary variable with a value of 1 for old and less developed democracies.

${ }^{2}$ BALCH_term - The change in the ratio of the government deficit to GDP in the two years preceding the election year, relative to the two previous years. BALCH_ey -The change in the government deficit ratio to GDP In the election year, compared to the previous year. GDPPC_gr - The average growth rate of real per-capita GDP during the leader's current term.

${ }^{3}$ GDPD_trend_ey - The change in the difference between real GDP and its trend, estimated using a Hodrick-Prescott filter, in the last year of the leader's term.

* - Significant at the 10 percent level; ** - Significant at the 5 percent level; ** - Significant at the 1 percent level. 
Table 6: Separate Effects of Global and Domestic Induced Growth, Inflation and Initial Political Strength on the Probability of Reelection ${ }^{1}$

\begin{tabular}{|c|c|c|c|c|c|c|}
\hline \multirow{2}{*}{ Dependent variable: REELECT } & \multicolumn{3}{|c|}{ Narrow Sample } & \multicolumn{3}{|c|}{ Expanded Sample } \\
\hline & (1) & (2) & (3) & (4) & (5) & (6) \\
\hline BALCH_term * developed ${ }^{2}$ & $\begin{array}{l}16.836^{\star *} \\
{[0.039]}\end{array}$ & $\begin{array}{l}19.922^{\star \star} \\
{[0.017]}\end{array}$ & $\begin{array}{l}19.382^{\star \star} \\
{[0.019]}\end{array}$ & $\begin{array}{l}10.443 \\
{[0.184]}\end{array}$ & $\begin{array}{l}12.574 \\
{[0.113]}\end{array}$ & $\begin{array}{l}12.123 \\
{[0.124]}\end{array}$ \\
\hline BALCH_term * less_developed ${ }^{2}$ & $\begin{array}{l}8.368 \\
{[0.537]}\end{array}$ & $\begin{array}{l}8.656 \\
{[0.498]}\end{array}$ & $\begin{array}{l}9.369 \\
{[0.481]}\end{array}$ & $\begin{array}{l}14.200^{*} \\
{[0.074]}\end{array}$ & $\begin{array}{l}13.970^{*} \\
{[0.076]}\end{array}$ & $\begin{array}{l}14.023^{\star} \\
{[0.077]}\end{array}$ \\
\hline BALCH_ey * developed ${ }^{2}$ & $\begin{array}{l}28.606^{\star \star} \\
{[0.017]}\end{array}$ & $\begin{array}{l}39.727^{\star \star \star} \\
{[0.001]}\end{array}$ & $\begin{array}{l}35.407^{\star * *} \\
{[0.004]}\end{array}$ & $\begin{array}{l}25.218^{\star *} \\
{[0.025]}\end{array}$ & $\begin{array}{l}33.667^{\star \star \star *} \\
{[0.002]}\end{array}$ & $\begin{array}{l}30.310^{\star \star \star} \\
{[0.007]}\end{array}$ \\
\hline BALCH_ey * less_developed ${ }^{2}$ & $\begin{array}{l}8.476 \\
{[0.551]}\end{array}$ & $\begin{array}{l}7.048 \\
{[0.618]}\end{array}$ & $\begin{array}{l}8.007 \\
{[0.586]}\end{array}$ & $\begin{array}{l}9.274 \\
{[0.376]}\end{array}$ & $\begin{array}{l}8.701 \\
{[0.380]}\end{array}$ & $\begin{array}{l}8.783 \\
{[0.384]}\end{array}$ \\
\hline GLOBAL_gr * Developed ${ }^{3}$ & $\begin{array}{l}20.544 \\
{[0.497]}\end{array}$ & $\begin{array}{l}23.324 \\
{[0.485]}\end{array}$ & $\begin{array}{l}18.613 \\
{[0.559]}\end{array}$ & $\begin{array}{l}25.893 \\
{[0.381]}\end{array}$ & $\begin{array}{l}28.879 \\
{[0.364]}\end{array}$ & $\begin{array}{l}25.576 \\
{[0.405]}\end{array}$ \\
\hline GLOBAL_gr * Less_Developed ${ }^{3}$ & $\begin{array}{l}17.196 \\
{[0.899]}\end{array}$ & $\begin{array}{l}19.899 \\
{[0.877]}\end{array}$ & $\begin{array}{l}22.966 \\
{[0.862]}\end{array}$ & $\begin{array}{l}1.646 \\
{[0.970]}\end{array}$ & $\begin{array}{l}3.730 \\
{[0.930]}\end{array}$ & $\begin{array}{l}3.705 \\
{[0.931]}\end{array}$ \\
\hline DOMESTIC_gr * developed ${ }^{3}$ & $\begin{array}{l}2.498 \\
{[0.833]}\end{array}$ & $\begin{array}{l}2.019 \\
{[0.861]}\end{array}$ & $\begin{array}{l}1.638 \\
{[0.887]}\end{array}$ & $\begin{array}{l}8.767 \\
{[0.455]}\end{array}$ & $\begin{array}{l}8.601 \\
{[0.451]}\end{array}$ & $\begin{array}{l}8.409 \\
{[0.462]}\end{array}$ \\
\hline DOMESTIC_gr * less_developed ${ }^{3}$ & $\begin{array}{l}36.968^{\star \star \star} \\
{[0.003]}\end{array}$ & $\begin{array}{l}34.522^{\star \star \star} \\
{[0.004]}\end{array}$ & $\begin{array}{l}35.156^{\star \star \star} \\
{[0.003]}\end{array}$ & $\begin{array}{l}32.427^{\star \star \star} \\
{[0.000]}\end{array}$ & $\begin{array}{l}32.623^{\star \star \star} \\
{[0.000]}\end{array}$ & $\begin{array}{l}32.960^{* \star \star} \\
{[0.000]}\end{array}$ \\
\hline INF_ey * Developed ${ }^{4}$ & $\begin{array}{l}-10.750^{\star \star *} \\
{[0.004]}\end{array}$ & & & $\begin{array}{l}-8.838^{\star \star} \\
{[0.013]}\end{array}$ & & \\
\hline INF_ey * Less_Developed ${ }^{4}$ & $\begin{array}{l}1.127 \\
{[0.720]}\end{array}$ & & & $\begin{array}{l}-0.628 \\
{[0.746]}\end{array}$ & & \\
\hline INFCH_ey * Developed ${ }^{4}$ & $\begin{array}{l}-10.268^{\star \star} \\
{[0.038]}\end{array}$ & $\begin{array}{l}-10.846^{\star *} \\
{[0.027]}\end{array}$ & $\begin{array}{l}-15.075^{\star \star} \\
{[0.014]}\end{array}$ & $\begin{array}{l}-11.433^{\star \star} \\
{[0.021]}\end{array}$ & $\begin{array}{l}-11.824^{\star *} \\
{[0.013]}\end{array}$ & $\begin{array}{l}-15.790^{\star *} \\
{[0.011]}\end{array}$ \\
\hline INFCH_ey * Less_Developed ${ }^{4}$ & $\begin{array}{l}2.143 \\
{[0.656]}\end{array}$ & $\begin{array}{l}2.020 \\
{[0.677]}\end{array}$ & $\begin{array}{l}2.401 \\
{[0.627]}\end{array}$ & $\begin{array}{l}0.270 \\
{[0.855]}\end{array}$ & $\begin{array}{l}-0.043 \\
{[0.971]}\end{array}$ & $\begin{array}{l}-0.008 \\
{[0.995]}\end{array}$ \\
\hline Average_INF * Developed ${ }^{4}$ & & & $\begin{array}{l}-3.647^{\star \star} \\
{[0.045]}\end{array}$ & & & $\begin{array}{l}-2.929 \\
{[0.118]}\end{array}$ \\
\hline PARTY ${ }^{5}$ & $\begin{array}{l}3.215^{\star \star} \\
{[0.012]}\end{array}$ & $\begin{array}{l}2.699 * * \\
{[0.026]}\end{array}$ & $\begin{array}{l}2.943^{\star \star} \\
{[0.016]}\end{array}$ & $\begin{array}{l}2.623^{\star \star} \\
{[0.013]}\end{array}$ & $\begin{array}{l}2.387^{\star \star} \\
{[0.019]}\end{array}$ & $\begin{array}{l}2.545^{\star \star} \\
{[0.013]}\end{array}$ \\
\hline VOTES $^{6}$ & $\begin{array}{l}1.719 \\
{[0.223]}\end{array}$ & $\begin{array}{l}1.440 \\
{[0.292]}\end{array}$ & $\begin{array}{l}1.478 \\
{[0.283]}\end{array}$ & $\begin{array}{l}1.257 \\
{[0.269]}\end{array}$ & $\begin{array}{l}1.121 \\
{[0.313]}\end{array}$ & $\begin{array}{l}1.175 \\
{[0.293]}\end{array}$ \\
\hline Developed Countries & $\begin{array}{l}1.817 \\
{[0.576]}\end{array}$ & $\begin{array}{l}0.855 \\
{[0.780]}\end{array}$ & $\begin{array}{l}1.427 \\
{[0.650]}\end{array}$ & $\begin{array}{l}0.673 \\
{[0.606]}\end{array}$ & $\begin{array}{l}0.105 \\
{[0.932]}\end{array}$ & $\begin{array}{l}0.446 \\
{[0.721]}\end{array}$ \\
\hline New Democracies & $\begin{array}{l}1.053^{\star \star} \\
{[0.043]}\end{array}$ & $\begin{array}{l}0.697 \\
{[0.123]}\end{array}$ & $\begin{array}{l}0.996 * \\
{[0.055]}\end{array}$ & $\begin{array}{l}0.530 \\
{[0.150]}\end{array}$ & $\begin{array}{l}0.340 \\
{[0.315]}\end{array}$ & $\begin{array}{l}0.480 \\
{[0.186]}\end{array}$ \\
\hline Majoritarian Electoral System & $\begin{array}{l}0.786^{\star} \\
{[0.056]}\end{array}$ & $\begin{array}{l}0.707^{\star} \\
{[0.077]}\end{array}$ & $\begin{array}{l}0.70{ }^{\star} \\
{[0.079]}\end{array}$ & $\begin{array}{l}0.544 \\
{[0.105]}\end{array}$ & $\begin{array}{l}0.550^{*} \\
{[0.095]}\end{array}$ & $\begin{array}{l}0.537 \\
{[0.107]}\end{array}$ \\
\hline Constant & $\begin{array}{l}-3.086 \\
{[0.328]}\end{array}$ & $\begin{array}{l}-2.607 \\
{[0.377]}\end{array}$ & $\begin{array}{l}-2.911 \\
{[0.340]}\end{array}$ & $\begin{array}{l}-2.061^{*} \\
{[0.071]}\end{array}$ & $\begin{array}{l}-1.994^{\star} \\
{[0.056]}\end{array}$ & $\begin{array}{l}-2.118^{\star \star} \\
{[0.046]}\end{array}$ \\
\hline Pseudo $\mathrm{R}^{2}$ & 0.153 & 0.131 & 0.142 & 0.139 & 0.127 & 0.132 \\
\hline LR(chi2) & 43.509 & 37.800 & 40.575 & 54.700 & 49.808 & 52.019 \\
\hline Akaike's criteria & 313.42 & 318.56 & 316.84 & 419.52 & 423.25 & 422.73 \\
\hline Schwartz's criteria & 372.44 & 374.12 & 375.87 & 484.10 & 484.04 & 487.31 \\
\hline Observations & 238 & 238 & 238 & 330 & 330 & 330 \\
\hline
\end{tabular}

${ }^{1}$ For variables definitions see Appendix I. The figures in the table are logit coefficients and the figures in the parantheses are P-values calculated on the basis of robust standard errors. An asterisk $\left(^{*}\right)$ indicates multiplication by the binary variable that follows.developed - A binary variable with a value of 1 for developed countries, less_developed - A binary variable with a value of 1 for less developed countries. ${ }^{2}$ BALCH term - The change in the ratio of the government deficit to GDP in the two years preceding the election year, relative to the two previous years. BALCH_ey - The change in the government deficit ratio to GDP In the election year, compared to the previous year. ${ }^{3}$ DOMESTIC_gr , GLOBAL_gr - The contribution of domestic and external factors to the growth rate of real per-capita GDP during the leader's current term, respectively.

${ }^{4}$ INF_ey - The inflation rate in the election year. INFCH_ey - The increase in the inflation rate from the year preceding the election year to the election year. Average_INF - The average rate of inflation rate during the leader's current term.

${ }^{5}$ PARTY - The percent of seats in the parliament held by the leader's party, receives the value 0 in a presidential system.

${ }^{6}$ VOTES - The percent of the votes received by a leader in a presidential system in the first round of the previous elections.

* - Significant at the 10 percent level; ** - Significant at the 5 percent level; *** - Significant at the 1 percent level. 